\title{
遺伝子解析による疾病発症のメカニズム解明及び創薬
}

\author{
菱田友昭

\section{Genetic Approaches for the Elucidation of Disease Development Mechanisms and the Creation of Innovative Medicines}

\author{
Tomoaki HISHIDA \\ Department of Molecular Biology, Graduate School of Pharmaceutical Sciences, Nagoya City University, \\ 3-1 Tanabe-dori, Mizuho-ku, Nagoya City 467-8603, Japan
}

2001 年 11 月にグリベック (一般名 : イマチニブ) が日本で認可されて以来，わが国でも分子標的治療 薬が癌治療に本格的に使用されるようになり始め た. 分子標的治療薬は癌細胞特異的な因子をターゲ ットとするため, 副作用の少ない, より良い薬剂で あると認識されている.このような背景のもとで分 子標的治療薬の開発が進められてきた一方, 従来の 抗癌剂とは性格の異なる副作用の問題が取り上げら れたのも記憶の新しいところである。したがって, その安全性や有用性についてはまだまだ詳細に検討 していく必要性があるものの, これらの薬物には大 きな期待が寄せられている.

癌のみならず，免疫疾患，神経疾患，さらには糖 尿病といった多因子疾患においても，疾病発症に関 わる責任遺伝子に注目した創薬開発が進んでいくこ とが期待されている。事実，ゲノムワイドな解析な どにより, 疾病に関与する遺伝子が次々と明らかに されており, ポストゲノム時代の生命科学の華々し い成果は, 枚挙に睱が無い程である.このような様 々な遺伝子解析の結果, 疾病の責任遺伝子について の知見が積み重なり，こうしたことが癌治療にとど まらず幅広いフィールドにおける創薬の原動力にな ることは疑問の余地が無いところである.このよう な動向を考慮すると，創薬開発には，まず創薬の対 象となる疾病がどのようなメカニズムにより発症す るのかを解明することが必要不可欠であると考えら れる，疾病発症のメカニズムを解明することができ

名古屋市立大学大学院薬学研究科分子生物薬学分野 (干467-8603 名古屋市瑞穂区田辺通 3-1) e-mail: p032756@phar.nagoya-cu.ac.jp 日本薬学会第 126 年会シンポジウム GS2 序文
れば，疾病発症の予防や治療につなげることができ るからである.

疾病発症の原因の多くは, 細胞機能の異常で説明 されるようになってきた，細胞は，外界の情報，す なわち様々な生理活性物質や物理刺激等に反応して 細胞内機能を調節する能力を有している。 それぞれ の刺激に対して特異的なシグナルを核内に伝達し, 核内で情報を処理し，遺伝子発現を経て細胞増殖や 分化, 恒常性の維持, 細胞の生死といつた形で巧妙 に応答するのである。こうしたシグナル伝達には, $\mathrm{G}$ タンパク質や，核内受容体，転写因子，酵素な どが重要な役割を果たしているが，これらのシグナ ル伝達を規定する因子の 1 つないし複数に変異が生 じたり，こうした因子の発現量が適切でないとシグ ナル伝達に異常を来し, 疾病が発症することが知ら れるようになつた。疾病発症に関与する様々な因子 が単離，同定され，こうした分子の機能が解明され つつある今日においては, 疾病発症の原因である分 子やシグナルの解明から創薬に結実させることが創 薬の主流になりつつある.

このような動向を受けて, 日本薬学会第 126 年会 では「遺伝子解析による疾病発症のメカニズム解明 及び創薬」のタイトルの下で大学院生シンポジウム を行った. 当シンポジウムでは生活習慣病や癌, 神 経疾患, 免疫疾患などの様々な分野で精力的に研究 されている大学院生に発表して頂いた.いずれの演 題も興味深い演題であったが，本稿ではこれらの演 題のうち, 生活習慣病と神経疾患について発表頂い たシンポジストに執筆をお願いし，発表内容を基に して疾病発症のメカニズム解明並びに創薬について の現状とその将来展望を概説して頂いた. 
生活習慣病に関連するものとして, 肥満形成のフ アーストステップである脂肪細胞分化を制御する新 規遺伝子群の解析について (城村の稿)，インスリ ンシグナルを制御する転写因子 EPAS1 (endothelial PAS domain protein 1) の機能について（和田の 稿)，脂質代謝，糖代謝の調節の鍵酵素として知ら れるピルビン酸脱水素酵素キナーゼ 4 (PDK4) の 発現制御について（荒木の稿），それぞれシンポジ ストの研究結果をもとに最新の知見を紹介して頂い た。また，神経変性疾患の 1 つである副腎白質ジス トロフィーの責任遺伝子, ALDP (adrenoleukodystrophy protein）についての細胞内動態の研究結果 と創薬の可能性について解説して頂いた(高橋の稿).

当シンポジウムでは, 様々な因子の機能解析結果 から疾病発症メカニズムを考察し, 創薬の可能性に
ついて討論した。 ヒトゲノム配列が明らかにされ， 生命科学の技術開発が盛んに行われている今日こ そ，どの因子がどのような疾病に関与するのか，民゙ の因子のどのような異常によって疾病が発症するの か，また SNPs などの一人一人の遺伝的個性がどの ように疾病に反映されているのか，などの研究が今 後ますます重要になってくると考えられる．こうし た意識を持ち，創薬開発を進めていくことが非常に 重要であると考えられる，そのため，本特集が，一 人でも多くの読者の興味を呼び起こし，少しでも今 後の研究の一助になることができればと願っている.

最後に, 御多忙のところ貴重な時間を割いてご執 筆頂いた各シンポジストの方々に心より感謝申し上 げます。 